\title{
CONTRIBUIÇÕES SOCIOLÓGICAS DE JÜRGEN HABERMAS PARA OS ESTUDOS ORGANIZACIONAIS
}

JÜRGEN HABERMAS' SOCIOLOGICAL CONTRIBUTIONS TO ORGANIZATIONAL STUDIES

Recebido em 16.12.2019 Aprovado em 28.03.2020

Avaliado pelo sistema double blind review DOI: https://doi.org/10.12712/rpca.v14i1.40097

\section{Ewerton Roberto Inocêncio}

ewerton.in@gmail.com

Programa de Pós-Graduação em Administração/Universidade Estadual de Londrina - Londrina/Paraná, Brasil ORCID: $\underline{\text { https://orcid.org/0000-0001-8624-2956 }}$

\section{Ricardo Lebbos Favoreto}

ricardo.lfavoreto@gmail.com

Programa de Pós-Graduação em Administração/Universidade Estadual de Londrina - Londrina/Paraná, Brasil ORCID: https://orcid.org/0000-0002-2878-0681

\section{Resumo}

Objetiva-se neste artigo identificar as contribuições habermasianas para os estudos organizacionais na área de Administração no cenário nacional atual. Emprega-se, para tanto, uma abordagem quantitativa e qualitativa. O levantamento bibliográfico procedeu-se nos principais periódicos nacionais da área. A etapa quantitativa identifica os periódicos mais receptivos a publicações, os autores mais produtivos e a evolução histórica do volume de publicações. A etapa qualitativa identifica os temas acolhedores dos aportes habermasianos, as obras e os conceitos habermasianos presentes nas publicações. Destacam-se os temas "Educação" e "Teoria das Organizações" e a obra "Teoria do Agir Comunicativo".

Palavras-chave: Habermas. Ação. Racionalidade. Mundo da Vida. Sistema.

\begin{abstract}
This article aims to identify the Habermasian contributions to the organizational studies in the area of administration in the current national scenario. A quantitative and qualitative approach is used. The bibliographic survey was carried out in the main national journals of the area. The quantitative stage identifies the most receptive journals, the most productive authors and the historical evolution of the volume of publications. The qualitative stage identifies the welcoming themes of the Habermasian contributions, the Habermasian works and concepts present in the publications. We highlight "Education" and "Theory of Organizations" and, the work "Theory of Communicative Action".
\end{abstract}

Keywords: Habermas. Action. Rationality. Lifeworld. System. 


\section{Introdução}

Os estudos organizacionais podem ser caracterizados como discursos, materializados em uma aglomeração de textos (e, pode-se acrescer, falas) que demarcam um espaço discursivo relacionado ao fenômeno organizacional; e, como tais, dotam-se de poder de conhecimento e reivindicam para si a correspondente autoridade sobre a fala, incluindo ou excluindo (WESTWOOD; CLEGG, 2003). Os estudos organizacionais em Administração, historicamente, tendem ao funcionalismo, um óbice a que visões críticas e inovadoras floresçam nesse espaço discursivo (VERGARA; CALDAS, 2005; SUDDABY; HARD; HUY, 2011). A despeito disso, abordagens críticas capazes de confrontar e desafiar o mainstream, ao explorarem novos caminhos centrados na busca por emancipação, também se fazem presentes na área, ganhando maior destaque a partir da década de 1990 (FOURNIER; GREY, 2000). Uma delas fundamenta-se no referencial habermasiano. Neste artigo, procede-se a uma exploração bibliográfica, no espaço científico nacional, dos estudos organizacionais da área de Administração baseados na sociologia de Jürgen Habermas.

Diversas são as técnicas disponíveis para avaliação da evolução da ciência, entre as quais destaca-se a bilbliometria, por meio da qual se observam fatos como publicações, autores, palavras-chave, citações e periódicos receptores de publicações (PAO, 1989). A técnica blibliométrica também pode servir para análise de citações e da produtividade científica dos pesquisadores (PRITCHARD, 1969). Para operar a exploração bibliográfica proposta, valeu-se de alguns procedimentos básicos da bibliometria, detalhados na seção sequente.

Jürgen Habermas é um filósofo e sociólogo inscrito na segunda geração da Escola de Frankfurt. Nascido em 18 de junho de 1929, em Düsseldorf, na Alemanha, realizou seus estudos na Universidade de Bonn, onde obteve o título de doutor em Filosofia, em 1954. Sua ampla produção abrange temas diversos, como racionalidade, identidade, esfera pública, direito, religião, democracia, cujos exames são permeados pela particular abordagem crítica que norteia seu trabalho. Entre suas obras, destacam-se títulos deveras notórios, a exemplo de "Técnica e ciência como ideologia" (HABERMAS, 1968), "Teoria do agir comunicativo" (HABERMAS, 1981a; 1981b) e "A inclusão do outro" (HABERMAS, 1996). A obra habermasiana ocupa lugar de saliência nas contemporâneas filosofia e sociologia. Os prêmios Leibniz de 1986 e Kyoto de 2004 são reconhecimentos simbólicos da estatura do autor. É notável intervenção que Habermas tem, há décadas, por diversos meios, realizado no espaço público (DUPEYRIX, 2012).

A obra magna de Habermas é "Teoria do agir comunicativo", na qual se apresenta uma teoria da sociedade de alta envergadura, nos moldes da teoria crítica, autorreflexiva e orientada para a emancipação. Nela, o autor trabalha na célebre distinção entre as ações sociais comunicativa e estratégica - a primeira, guiada pela razão comunicativa, imbuída no processo de argumentação, almejante de entendimento; a segunda, guiada pela razão instrumental, almejante de êxito. O projeto social crítico habermasiano balizase fundamentalmente no primeiro tipo.

Em condições ideais, o processo argumentativo próprio da ação comunicativa não deve impor qualquer obstáculo à participação igualitária de todos os atores capazes de contribuir, e seu principal objetivo é a obtenção do consenso (HABERMAS, 2012). Compreender o qualificativo "comunicativo" que denota a ação comunicativa é crucial para a apreensão consequente de diversos conceitos e temas abordados pelo autor, destacadamente a racionalidade e a díade mundo da vida e sistema.

O projeto emancipatório habermasiano insere-se em uma teoria social de grande envergadura. Não constituem, porém, seu escopo especificidades da Administração. A aproximação entre a teoria habermasiana e a Administração não se realiza sem certa dose de ousadia. Trata-se de um movimento nada fácil e, quando viabilizado, altamente profícuo. Note-se: 


\begin{abstract}
Outro quesito importante diz respeito ao entorno em que se dá a inserção do pensamento habermasiano na Administração. Como se destacou, sua recepção acontece, geralmente, por pesquisas críticas. Importa recordar, então, que, diferentemente dos referenciais de parcela significativa das pesquisas de linhagem crítica, o projeto habermasiano prevê a possibilidade de emancipação social. Mantém diante de si um projeto de modernidade inacabado, com potencial de efetivação. A Administração (mencionando-se já o ponto próximo) pode concorrer para tanto. O método crítico desenrola-se, como se apontou, por meio de diagnóstico e prognóstico, o que, seguindo-se a tradição frankfurtiana, procede-se multidisciplinarmente. O conhecimento gerado na Administração é não apenas útil como também fundamental para a compreensão da realidade moderna, notadamente porque dela não é possível excluir o mercado nem as organizações. No mercado, aliás, veem-se assentadas características fundamentais dos sistemas. Organizações são partes suas. (FAVORETO; NOGUEIRA; BANNWART JUNIOR, 2019, p. 9-10).
\end{abstract}

Em texto diverso (BANNWART JUNIOR; FAVORETO; NOGUEIRA, 2018), os autores resgatam uma notória díade embasadora do pensamento habermasiano, aquela que se estabelece na dialética entre "trabalho" e "interação". Chamam atenção para a insistência de Habermas em preservar apartadas as esferas de trabalho e interação, com o fito de desviar-se da (poder-se-ia afirmar tentadora) conjugação entre progresso técnico e comportamento racional. Relembram, complementarmente, um dos avisos alardeados pela teoria crítica: o progresso técnico por si não é portador de toda emancipação. A ideologia tecnocrática, comum no meio corporativo, justifica o especial enfoque que a teoria crítica e particularmente o pensamento habermasiano pode prover em se tratando dos estudos organizacionais. Nas palavras dos autores, "aos estudos organizacionais críticos a reflexão habermasiana deixa, portanto, um significativo legado" (p. 6).

Neste artigo, as publicações que se utilizam de referencial habermasiano são mapeadas por uma dupla perspectiva, quantitativa e qualitativa. A análise quantitativa tem o intuito de identificar os periódicos, o período, os autores, e suas respectivas áreas de atuação, das publicações. A análise qualitativa volta-se para os temas das publicações, os trabalhos de Habermas mais citados e as metodologias utilizadas para a condução das pesquisas. Ressalte-se que o escopo recaiu sobre artigos do campo de estudos organizacionais publicados em periódicos nacionais.

Nas seções subsequentes, detalham-se os procedimentos metodológicos da pesquisa, indicando-se as etapas percorridas na sua execução. Em sequência, são expostos e discutidos os dados obtidos pela análise quantitativa e, logo após, conduzida a análise qualitativa, oriunda de diagnóstico operacional e da interpretação das publicações. Na parte final, apresenta-se uma síntese dos resultados e tecem-se considerações finais, nas quais se sugestionam orientações para pesquisas futuras.

\title{
Procedimentos metodológicos
}

A fim de desempenhar o objetivo proposto, realizou-se uma exploração bibliográfica, norteada por verificações bibliométricas. Para a análise dos resultados, apoia-se na utilização de estatística descritiva e, em grau bastante moderado, na análise de conteúdo (ver VANTI, 2002; BOSCHIVIER, GUEDES 2005; GIL, 2010; LAKATOS; MARCONI, 2011).

Segundo Guedes e Boschiver (2005), a bibliometria também pode ser compreendida como uma ferramenta estatística, um instrumento quantitativo que contribui para a avaliação da produção científica, gerando indicadores que possibilitam tratar a informação. Os autores ressaltam o papel das citações, por meio das quais é praticável observar o relacionamento dos autores que se citam e eventual padrão de relações múltiplas, viabilizando-se o diagnóstico das frentes de pesquisa de uma área científica. Vanti (2002) frisa que não há, todavia, um consenso entre os estudiosos da ciência da informação quando se trata de mensuração e avaliação da produção intelectual acadêmica, o que faz de estudos desse tipo algo desafiante. 
Particularmente, o estudo empreendido toma por base a estrutura metodológica do trabalho realizado por Letrari, Chiba e Borim-de-Souza, que visou identificar as contribuições de Pierre Bourdieu para a área de Administração no âmbito de acervos internacionais (LETRARI; CHIBA, BORIM-DE-SOUZA, 2018). Como sugestão de pesquisas futuras, o trabalho inclusive incentiva a realização de investigações semelhantes relacionadas a outros teóricos. Saliente-se que a pesquisa obteve significativa repercussão entre pesquisadores da área de estudos organizacionais e, até mesmo, recebeu prêmio de melhor trabalho da área em um dos maiores eventos acadêmicos do país.

Num primeiro momento, efetuou-se uma pesquisa documental de artigos nos periódicos eleitos. Essa etapa caracteriza-se como quantitativa, pois recorreu-se a métodos estatísticos para quantificação dos dados e estabelecimento de padrões (LAKATOS; MARCONI, 2011). Além disso, essa etapa tem viés descritivo, pois procurou-se descrever as características da amostra (ou população) do fenômeno estudado (GIL, 2010). Foram levantadas, classificadas e mensuradas informações que permitissem pormenorizar as publicações quanto à autoria, às instituições vinculadas e aos periódicos com maior produtividade.

Essa etapa iniciou-se pela delimitação, para a coleta de dados, dos periódicos nacionais que constituem referências na área de Administração, tomando-se por base a avaliação Qualis de periódicos realizada pela CAPES no quadriênio (2013-2016). Detectaram-se, de início, 1141 títulos ligados a periódicos científicos nacionais e estrangeiros na área de Administração, Ciências Contábeis e Turismo, classificados como A1, A2 ou B1 (classificação vigente em maio 2019). Desse rol, excluíram-se os títulos ligados aos estrangeiros, remanescendo 192 títulos. Esse foi o primeiro movimento em direção a uma amostragem não-probabilística por julgamento, que, segundo Gil (2010), caracteriza-se pela seleção de um subgrupo representante da população, a partir de informações disponíveis e conhecimento prévio da população e do subgrupo.

Apuraram-se nesses periódicos artigos, publicados desde o ano de fundação do periódico até maio de 2019, que contêm a palavra Habermas no título, no resumo ou entre as palavras-chave. Resultaram dessa busca 219 publicações em 61 periódicos. Desse montante, foram considerados apenas os periódicos que possuíam como escopo a área de Administração, resultando numa amostra final de 46 publicações em 10 periódicos.

Ato contínuo, levantaram-se os anos de publicação dos artigos. Levantaram-se, ainda, informações concernentes aos autores - distribuição das publicações por quantidade de autores, área acadêmica de atuação e instituições a que se vinculam. Nessa etapa, constataram-se também os periódicos com maior quantidade de publicação.

Rematada a análise quantitativa e descritiva, os artigos foram analisados sob perspectiva qualitativa e exploratória. De acordo com Gil (2010, p. 26), "as pesquisas exploratórias têm como propósito proporcionar maior familiaridade com o problema, com vistas a torná-lo mais explícito ou a construir hipóteses." Destarte, nessa etapa qualitativa e exploratória, teve-se por objetivo ir além da mensuração descritiva levada a cabo na análise prévia, quantitativa e descritiva, procurando-se explorar nos artigos analisados as obras de Habermas mais utilizadas como referências, as teorias habermasianas mais abordadas nas relações com os estudos organizacionais na área de Administração e as abordagens metodológicas predominantes nas construções desses artigos. Para essa finalidade, os artigos selecionados foram submetidos a uma examinação e categorização qualitativa básica (MERRIAN, 2009). Em suma, buscou-se adentrar nas contribuições teóricas de Habermas no campo visado, perscrutando-se a forma como delas têm-se apropriado as pesquisas em estudos organizacionais na área de Administração.

\section{Apresentação e análise dos resultados}

Antes da apresentação dos resultados, ressalte-se que o referencial crítico habermasiano tem sido apontado como de grande valia para os estudos organizacionais, tanto por autores nacionais como por 
estrangeiros. Por exemplo, Gibson Burrel, coautor de "Sociological paradigms and organizational analysis" (1979), uma das obras mais influentes do campo dos estudos organizacionais, já em 1988 apontava para as possibilidades contributivas do referencial habermasiano. Abordando o debate entre as correntes filosóficas e sociológicas modernistas e pós-modernistas que influenciavam os estudos organizacionais, Cooper e Burrel (1988) apontaram Habermas como autor representativo dos modernistas críticos, a oferecer um suporte valioso para as abordagens modernistas de organização, que veem a organização como expressão da racionalidade humana e acreditam que o sujeito racional pode organizar-se. Em texto publicado na década seguinte, Burrell voltou a destacar a contribuição de Habermas, salientando o papel desempenhado pelo projeto modernista nos estudos organizacionais (BURRELL, 1994).

Em âmbito nacional, recentemente, a autora Ana Paula Paes de Paula (2016) empreendeu um estudo de cunho epistemológico fundamentado na teoria habermasiana dos interesses cognitivos. A partir de uma extensa bibliografia, a autora realizou reflexões críticas sobre o modelo matricial de Burrel e Morgan (1979), o qual fomentaria uma guerra paradigmática infrutífera entre as abordagens do campo, por estar baseado na lógica kuhninana de desenvolvimento da ciência. Na tentativa de superar esses impasses, a autora propôs uma nova base teórica para discussões epistemológicas, amparada no modelo habermasiano de "Conhecimento e interesse", que conjuga interesses técnicos, práticos e emancipatórios. Nas ciências sociais, e também nos estudos organizacionais, a propulsão do conhecimento seria motivada por interesses, não por revoluções paradigmáticas.

Em artigo publicado no ano passado (2019), Lara e Vizeu demonstram o potencial crítico da obra habermasiana, contra tentativas de abordagens superficiais que distanciam Habermas do projeto crítico anunciado por Horkheimer. Um dos argumentos apresentados sustenta que o referencial habermasiano, ao buscar, por meio da racionalidade comunicativa, a emancipação das relações de dominação social estabelecidas pelo capitalismo, cumpre com um dos princípios basilares da Teoria Crítica, o de buscar na própria realidade social as potencialidades para a superação dos obstáculos impostos pela dominação (LARA; VIZEU, 2019).

Instigada por trabalhos como os citados, esta pesquisa procurou investigar o cenário da produção nacional fundamentada no referencial crítico habermasiano. Há ciência de que, como anotam Lara e Vizeu (2019, p. 2), "a apreciação da Teoria Crítica em estudos organizacionais foi e continua sendo um trabalho de resistência à hegemonia da concepção positivista de ciência nesse campo de estudos", e os resultados da pesquisa, de certo modo, retratam como essa resistência, fundamentada no pensamento habermasiano, tem-se desenvolvido no cenário nacional

\section{Análise Quantitativa e Descritiva}

Pela análise quantitativa e descritiva, identificaram-se informações sobre autoria das publicações, área de estudo dos pesquisadores e instituições a que os pesquisadores se vinculam, assim como os periódicos que contêm mais publicações e as regiões nacionais em que se concentram.

O principal volume de publicações está no periódico Cadernos EBAPE.BR, da Fundação Getúlio Vargas; são 16 publicações, aproximadamente $35 \%$ do total. A posição seguinte é ocupada pelo periódico Revista de Administração Pública, também da Fundação Getúlio Vargas, repositório de 10 publicações, aproximadamente $22 \%$ do total. 
Quadro 1 - Quantidade de publicações por periódico

\begin{tabular}{|l|l|c|}
\hline Periódico & Instituição vinculada & $\begin{array}{l}\mathbf{N}^{\mathbf{0}} \\
\text { Artigos }\end{array}$ \\
\hline Cadernos EBAPE.BR & Fundação Getúlio Vargas & $\mathbf{1 6}$ \\
\hline $\begin{array}{l}\text { Revista de Administração } \\
\text { Pública }\end{array}$ & Fundação Getúlio Vargas & $\mathbf{1 0}$ \\
\hline Organizações \& Sociedade & Universidade Federal da Bahia & $\mathbf{5}$ \\
\hline $\begin{array}{l}\text { Administração Pública e Gestão } \\
\text { Social }\end{array}$ & Universidade Federal de Viçosa & $\mathbf{4}$ \\
\hline $\begin{array}{l}\text { Revista de Administração De } \\
\text { Empresas }\end{array}$ & Fundação Getúlio Vargas & $\mathbf{4}$ \\
\hline $\begin{array}{l}\text { Revista de Administração } \\
\text { Mackenzie }\end{array}$ & Universidade Presbiteriana Mackenzie & $\mathbf{2}$ \\
\hline Revista de Gestão & Universidade de São Paulo & $\mathbf{2}$ \\
\hline Brazilian Administration Review & $\begin{array}{l}\text { Associação Nacional de Pós-Graduação e Pesquisa em } \\
\text { Administração }\end{array}$ & $\mathbf{1}$ \\
\hline Brazilian Business Review & $\begin{array}{l}\text { Fundação Instituto Capixaba de Pesquisas em Contabilidade, } \\
\text { Economia E Finanças }\end{array}$ & $\mathbf{1}$ \\
\hline $\begin{array}{l}\text { Revista de Administração } \\
\text { Contemporânea }\end{array}$ & $\begin{array}{l}\text { Associação Nacional de Pós-Graduação e Pesquisa em } \\
\text { Administração }\end{array}$ & $\mathbf{1}$ \\
\hline
\end{tabular}

Fonte: elaborado pelos autores.

As 46 publicações analisadas são assinadas por 74 autores, sendo José Roberto Pereira e Valderí de Castro Alcântara, ambos vinculados à Universidade Federal de Lavras, os que estão mais presentes nas publicações. José Roberto Pereira assina 8 publicações e Valderí de Castro Alcântara, 7. Eles aparecem em coautoria em 6 publicações. A vasta publicação de ambos autores neste recorte é condizente com as atividades acadêmicas que desenvolvem.

Um levantamento sobre os autores na plataforma CNPq aponta que a pesquisa de José Roberto Pereira volta a teoria da ação comunicativa para a construção e delimitação dos campos de pesquisa em gestão social e administração pública. Desde 2016, o autor mantém como coordenador um projeto de pesquisa intitulado "A ciência em circulação na esfera pública: análise do jornalismo científico das universidades federais de Minas Gerais", no qual emprega as reflexões habermasianas sobre esfera pública, opinião pública e agir comunicativo. Destaque-se também o registro de participação em eventos temáticos, como "XI Colóquio Habermas e II Colóquio de Filosofia da Informação 'Os limites para a liberdade comunicativa?", bem ainda de apresentação de trabalhos com embasamento nas obras de Habermas, como no Encontro Nacional dos Pesquisadores em Gestão Social (ENAPEGS). Vale notar que José Roberto Pereira foi orientador de mestrado de Valderí de Castro Alcântara, cuja dissertação tem por título "Mundo-da-vida e Sistema: o Lócus da Gestão Social sob a Abordagem Habermasiana".

Além da dissertação, também a tese de doutorado de Valderí de Castro Alcântara, acompanhada pelo mesmo orientador, fundamenta-se no pensamento habermasiano. Seu título é: "Práticas de gestão das águas minerais e os movimentos deliberativos da gestão social no circuito das águas no sul de Minas Gerais". Tal como o orientador, o autor tem participado de eventos cuja temática gravita em torno da gestão social. Desde 2016, participa do projeto coordenado por José Pereira, "Gestão social, esfera pública e governança deliberativa no "Circuito Turístico das Águas", que tem como um dos principais objetivos incrementar o conhecimento da categoria "esfera pública" em Habermas e suas contribuições para pesquisas empíricas nacionais em contextos conflituosos. A relação entre orientando e orientador contribui para explicar o volume de produções assinadas em coautoria. 
$\mathrm{Na}$ amostra dos artigos selecionados, sublinhe-se o significativo número de publicações assinadas por um único autor apenas: 20, aproximadamente $43 \%$ do total, sendo que 8 delas foram publicadas pelo periódico Revista de Administração Pública e 4, pelo periódico Revista de Administração de Empresas, ambos da Fundação Getúlio Vargas. Aliás, outro fator a sublinhar é a abertura dada pelos periódicos da Fundação Getúlio Vargas para publicações fundamentadas no pensamento habermasiano.

O ano mais frutífero foi 2014, com 5 publicações, todas no periódico Cadernos Ebape.Br. Note-se que 4 desses artigos foram publicados em volume de chamada especial "Estudos Organizacionais e Filosofia". Em referência a esse volume, o editor menciona que se trata de uma continuidade da proposta do periódico de promover a divulgação de artigos com abordagens críticas do fenômeno organizacional, pondo em pauta um dos principais teóricos críticos da atualidade, Jürgen Habermas (TENÓRIO, 2014). Outros anos profícuos foram 2011, 2015 e 2018, com 4 publicações cada. Distintamente, no entanto, não se verifica nesses anos a mesma concentração de 2014. Não se identificou qualquer incentivo específico por parte das revistas para publicações de embasamento habermasiano. O periódico Cadernos Ebape.Br, embora não tenha realizado uma nova chamada especial direcionada para a discussão do pensamento habermasiano, conta com 1 publicação em 2011, 1 em 2015 e 2 em 2018.

Fator que pode contribuir para justificar variações no volume de publicações é o acolhimento de trabalhos por eventos científicos nacionais. Trabalhos críticos são contemplados no escopo de eventos importantes da área, tais como o Encontro de Estudos Organizacionais, da Associação Nacional de PósGraduação e Pesquisa em Administração (ENEO-ANPAD), o Encontro da ANPAD (EnANPAD) e o Congresso Brasileiro de Estudos Organizacionais, da Sociedade Brasileira de Estudos Organizacionais (CBEO-SBEO). ENEO e EnANPAD, com frequência, tem aberto espaço para estudos críticos, entre os quais os frankfurtianos. O CBEO, promovido desde 2013, tem-se marcado por discussões críticas de amplo espectro.

Vale relevar também que a análise dos anos de publicação aponta 3 publicações em 2019, o que demonstra um interesse recente pelo pensamento habermasiano. Destaque-se que, entre 2008 e 2019, sempre houve ao menos 1 publicação por ano. É nesse período de 12 anos que se concentra o maior número de publicações, 33, aproximadamente $72 \%$ do total.

Quadro 2 - Volume de publicações por ano

\begin{tabular}{|c|c|c|c|c|c|c|c|c|c|c|c|}
\hline Ano & $\bar{\sigma}$ & $\tilde{\sigma}$ & 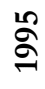 & ఏ & $\stackrel{2}{\stackrel{\sigma}{\sigma}}$ & ఫ્ડ & 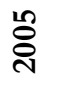 & ఫ్̊․ & $\stackrel{\infty}{\stackrel{ి}{ి}}$ & ڤ્ণે & $\begin{array}{c}\bar{\pi} \\
0 \\
H\end{array}$ \\
\hline $\mathbf{N}^{\circ}$ de publicações & 1 & 1 & 2 & 2 & 1 & 3 & 2 & 1 & 1 & 1 & 15 \\
\hline Ano & 을 & $\overline{\bar{\sigma}}$ & సี & 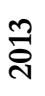 & $\stackrel{\Xi}{\tilde{~}}$ & $\stackrel{\text { กี }}{\tilde{ก}}$ & ֻั & 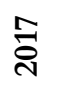 & $\stackrel{\infty}{\stackrel{\infty}{\tilde{~}}}$ & ڤิे & 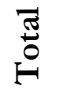 \\
\hline $\mathbf{N}^{o}$ de publicações & 2 & 4 & 2 & 2 & 5 & 4 & 2 & 3 & 4 & 3 & 31 \\
\hline
\end{tabular}

Fonte: elaborado pelos autores.

Identificou-se também que a Universidade de Lavras é a instituição com maior número de autores vinculados, 16, aproximadamente $22 \%$ do total. Trata-se de um número expressivo, uma vez que a segunda instituição foi a Pontifícia Universidade Católica de São Paulo, com 7 autores, aproximadamente $9 \%$ do total. Os demais 51 autores estão espalhados por 43 instituições.

Quanto à área de atuação, verificou-se que 48 autores, aproximadamente $65 \%$ do total, têm como área de atuação a Administração. Quatro autores, aproximadamente 5\% do total, têm como área de atuação a Sociologia, e os demais 30\% diversificam-se por outras áreas, como Filosofia, História, Antropologia, Linguística, Saúde Coletiva. Isso demonstra que, além de pesquisadores da própria área de Administração, 
outros de domínios diversos também têm apresentado interesse em contribuir com pesquisas em estudos organizacionais, na área de Administração, fundamentados no pensamento habermasiano.

\section{Análise Qualitativa-Exploratória}

Nesta etapa, identificaram-se as obras e teorias habermasianas mais utilizadas pelos autores em suas publicações e também as abordagens metodológicas empregadas. Analisando-se o conteúdo de cada artigo, verificaram-se os temas das publicações e as obras de Habermas mais presentes. Em seguida, averiguaram-se as teorias e os conceitos habermasianos discutidos nos temas das publicações. Nas 46 publicações, constataram-se os seguintes temas: Administração Pública, Comunicação, Economia Solidária, Educação e Teoria das Organizações.

\section{Quadro 3 - Quantidade de publicações por tema}

\begin{tabular}{|l|c|}
\hline Temas & $\mathbf{N}^{\mathbf{o}}$ de publicações \\
\hline Teoria das Organizações & 27 \\
\hline Educação - Pesquisa ensino em ADM & 10 \\
\hline Comunicação & 5 \\
\hline Administração pública & 3 \\
\hline Economia Solidária & 1 \\
\hline TOTAL & $\mathbf{4 6}$ \\
\hline
\end{tabular}

Fonte: elaborados pelos autores

As obras habermasianas mais referenciadas, aquelas que constaram mais vezes da lista de referência dos trabalhos, foram "Teoria do agir comunicativo: racionalidade da ação e racionalização social" e "Teoria do agir comunicativo: sobre a crítica da razão funcionalista", constituintes dos dois volumes da obra magna do autor.

Quanto ao método de pesquisa, o mais recorrente é o ensaio teórico, embora também se encontrem entre as publicações estudos de caso, o que indica a potencialidade da utilização do pensamento habermasiano não apenas em reflexões teóricas, como também em pesquisas empíricas. Destaca-se que esses estudos de caso, qualitativos, contrapõem-se à perspectiva positivista tradicional. Os casos analisam: organizações empresariais privadas de diferentes ramos; processos de gestão de programas sociais, festas tradicionais e territórios com participação de grupos diversos; instituições de ensino e organizações cooperativas. Observa-se que os estudos de caso estão relacionados a todos os temas apresentados na sequência deste trabalho. Destaque-se, por fim, que 3 desses estudos buscam entender o tipo de racionalidade a orientar as organizações. Para tanto, utilizam-se de um modelo desenvolvido por Maurício Serva (1997), pelo qual o conceito habermasiano de racionalidade comunicativa é aproximado do conceito de racionalidade substantiva de Guerreiro Ramos (SERVA, 1997a, 1997b; SILVA, 2011).

\section{Quadro 3 - Quantidade de publicações por método de pesquisa}

\begin{tabular}{|l|c|c|}
\hline \multicolumn{1}{|c|}{$\begin{array}{c}\text { Métodos de } \\
\text { pesquisa }\end{array}$} & $\mathbf{N}^{\mathbf{o}}$ de artigos & Proporção \\
\hline Ensaio teórico & 35 & $76 \%$ \\
\hline Estudo de caso & 11 & $24 \%$ \\
\hline TOTAL & $\mathbf{4 6}$ & $\mathbf{1 0 0 \%}$ \\
\hline
\end{tabular}

Fonte: elaborado pelos autores. 
Seguindo a proposta da análise qualitativa-exploratória, apresentam-se, na sequência, a descrição dos temas, das obras e das teorias habermasianas mais referenciadas, e também dos métodos de pesquisa empregados. Inicie-se pelos temas:

- Administração Pública: problematizam-se questões relacionadas a instituições e áreas públicas tais como prestação de serviço público, processo de licenciamento, parcerias entre entidades públicas e sociedade civil e transformações de espaços públicos.

- Comunicação: estudos relacionados às práticas comunicativas por parte de organizações ou de seus integrantes, como declarações de missões corporativas, relações de poder e violência por meio da comunicação, bem como sobre a ética na prática discursiva.

- Economia Solidária: abordam-se assuntos que discutem a cooperação entre indivíduos para a resolução de necessidades econômicas comuns, bem como a prática da gestão solidária.

- Educação: debatem-se o ensino, a pesquisa e à docência, tendo-se por foco, em alguns casos, o ensino em Administração.

- Teoria das Organizações: abrange discussões a respeito de teorias e conceitos relacionados aos estudos organizacionais de diferentes abordagens epistemológicas.

Destaque-se que, no tema Teoria das Organizações, debates em torno da "Gestão Social" são os mais presentes nos estudos dos autores mais produtivos, sendo centrais em 3 artigos que trabalharam em coautoria (ALCÂNTARA; PEREIRA, 2017; ALCÂNTARA et al., 2017; GARCIA et al., 2018). José Roberto Pereira possui ainda outro trabalho cujo tema central é "Gestão Social" e que não foi realizado em coautoria com Valderí de Castro Alcântara (PERES JÚNIOR; PEREIRA; DE OLIVEIRA, 2013). Além do diagnóstico dos temas, buscou-se entender a forma como os autores se apropriam em suas pesquisas do pensamento habermasiano. Nas seções seguintes, apresentam-se sucintamente as obras mais referenciadas e as noções a elas concernentes, bem ainda como elas são relacionadas com os temas manejados nas publicações.

\section{Obras de Jürgen Habermas mais Referenciadas: predominância da Teoria do Agir Comunicativo}

O levantamento das obras de Habermas permitiu verificar quais trabalhos do autor foram mais referenciados e como eles são relacionados com os temas das publicações. As obras de Habermas mais referenciadas são "Teoria do agir comunicativo: racionalidade da ação e racionalização social" e "Teoria do agir comunicativo: sobre a crítica da razão funcionalista", ambas referenciadas em 29 artigos. No quadro seguinte, listam-se todas as obras habermasianas utilizadas como referências nas publicações em análise e, em seguida, apresenta-se um breve resumo da obra mais referenciada, "Teoria do agir comunicativo", em seus dois volumes. 


\section{Quadro 5 - Obras referenciadas e quantidade de publicações}

\begin{tabular}{|c|c|}
\hline Obra & $\begin{array}{c}\text { Quantidade de } \\
\text { publicações em que } \\
\text { a obra é } \\
\text { referenciada }\end{array}$ \\
\hline A teoria do agir comunicativo: crítica a razão funcionalista vol. 2 & \multirow{2}{*}{29} \\
\hline A teoria do agir comunicativo: razão e a racionalização social vol. 1 & \\
\hline Consciência moral e agir comunicativo & \multirow{2}{*}{10} \\
\hline Direito e democracia: entre a facticidade e validade 2 & \\
\hline Conhecimento e interesse & \multirow[b]{2}{*}{7} \\
\hline $\begin{array}{l}\text { Mudança estrutural da esfera pública: investigações quanto a uma categoria de sociedade } \\
\text { burguesa. }\end{array}$ & \\
\hline Racionalidade e Comunicação & \multirow{2}{*}{6} \\
\hline Técnica e ciência como ideologia & \\
\hline Direito e democracia: entre a facticidade e validade & \multirow{2}{*}{5} \\
\hline O discurso filosófico da modernidade & \\
\hline Verdade e justificação: ensaios filosóficos & 4 \\
\hline A crise da legitimação no capitalismo tardio & \multirow{4}{*}{3} \\
\hline Comunicação política na sociedade mediática & \\
\hline Pensamento pós-metafísico: estudos filosóficos. & \\
\hline Teoría de la acción comunicativa: complementos y estudios prévios & \\
\hline $\begin{array}{l}\text { Entre fatos e normas: contribuições para uma teoria do discurso do direito e da } \\
\text { democracia. }\end{array}$ & \multirow{8}{*}{2} \\
\hline Outras reflexões sobre a esfera pública. & \\
\hline Para a reconstrução do materialismo histórico & \\
\hline Para o uso pragmático, ético e moral da razão prática & \\
\hline Passado como futuro & \\
\hline Pensamento pós-metafísico & \\
\hline Teoria e prática & \\
\hline Três modelos normativos de democracia & \\
\hline Outras obras & 1 \\
\hline
\end{tabular}

Fonte: elaborado pelos autores.

"Teoria do agir comunicativo" é uma obra extensa e multidisciplinar, dividida em dois volumes, na qual o autor realiza uma releitura de diversos autores clássicos, como Weber, Mead, Durkheim, Parsons, Marx, os frankfurtianos, Kant, Kolbergh, entre outros. Habermas pretende nela realizar uma mudança paradigmática da filosofia da consciência para o paradigma da linguagem, resgatando, de acordo com seu intuito, o potencial emancipatório da razão, visto com certa descrença pelos seus predecessores (NOBRE, 2008)

No primeiro volume, Habermas, primeiramente, resgata a noção de racionalidade, problematizando concepções correntes e chegando a uma nova proposta de racionalidade, inerente à ação comunicativa. Retoma, para tanto, alguns dos principais conceitos de ação social da teoria sociológica: ação orientada a fins, ação normativa, ação dramatúrgica. Essas formas de ação contam com a linguagem como meio de expressão, utilizada, porém, de modo atrofiado. A racionalidade inerente a cada uma dessas ações limitase ao respectivo mundo com o qual o ator se confronta (objetivo, social ou subjetivo) (HABERMAS, 2012a). 
Diante disso, Habermas propõe um novo modo de ação, a comunicativa, no qual a linguagem tem um papel central e a racionalidade amplia-se, considerando-se que o ator se refere simultaneamente aos três mundos. A razão comunicativa infunde-se no agir comunicativo, que visa o entendimento dos atores e procura fazer valer um enunciado por intermédio da argumentação. Esse tipo de racionalidade opõe-se à razão instrumental, orientadora da ação estratégica; esta, ampliação da ação teleológica weberiana, a qual objetiva o êxito pela escolha dos melhores fins (HABERMAS, 2012a).

Habermas utiliza-se de Weber não só para fundamentar a noção de ação estratégica. Weber é um dos autores mais relevantes na fundamentação da teoria do agir comunicativo. Habermas reinterpreta a teoria weberiana da racionalização, estendendo-a para além do prisma da racionalidade instrumental. $\mathrm{O}$ processo de racionalização social interpretado por Weber capta o esmaecimento das concepções religiosas e a concomitante racionalização das esferas da vida social. O tempo enfocado é a modernidade. O esforço habermasiano dirige-se a enxergar, nesse mesmo cenário (naturalmente estendido pelo decurso do tempo), a preservação, num outro modo de racionalidade, do que restou relegado no processo de racionalização (HABERMAS, 2012a).

$\mathrm{Na}$ parte final do primeiro volume, Habermas analisa a influência weberiana no pensamento marxista, que conduziu autores como Lukács, Adorno, Marcuse e Horkheimer a diagnósticos semelhantes em relação ao processo de racionalização. Tais visões, a despeito de distintas, compartilham um certo pessimismo em relação à realidade. A racionalização sob enfoque é justamente aquela da qual resultara perdas de liberdade e de sentido. Habermas pretende superar o ceticismo, dar à Teoria Crítica novo fôlego. Para isso, propõe, como se disse, uma nova forma de conceber a razão, substituindo o paradigma da consciência pelo da linguagem, pelo que visa, em suma, resgatar o potencial da racionalidade (HABERMAS, 2012a).

No segundo volume da obra, Habermas dá continuidade ao desenvolvimento da perspectiva sociológica proposta, que encampa a ação comunicativa. $\mathrm{Na}$ extensa análise procedida, Habermas justifica a incompletude das perspectivas correntes. Para ele, é necessária uma superação a partir de uma concepção que integre mundo vivido e sistema (HABERMAS, 2012b). O autor estende, então, a conceituação de mundo da vida, enxergando-o como horizonte social compartilhado, constituído de convicções de base, provenientes do saber decorrente das experiências vividas e especialmente da cultura e da linguagem. $\mathrm{O}$ mundo da vida não permanece, todavia, estático; pode modificar-se na medida em que aquilo que é tomado por certo é questionado. Assim sendo, o mundo vivido se torna local de mudança e de continuidade social (HABERMAS, 2012b).

A noção de sistema é desenvolvida particularmente no capítulo seis. $\mathrm{Na}$ sua base, destaque-se o pensamento de Parsons, que tentara formular uma teoria da ação social que integrasse a perspectiva sistêmica e a do ator. A crítica habermasiana, outra vez, dirige-se ao reducionismo que resulta da submissão da teoria da ação à visão sistêmica. Habermas adota alguns termos utilizados por Parsons, como o próprio termo "sistema", empregado para caracterizar estruturas sociais responsáveis pela reprodução material da sociedade, o estado burocrático e a economia, integrados por poder e dinheiro, respectivamente (HABERMAS, 2012b).

O último capítulo da obra apresenta uma reinterpretação de autores como Marx e Parsons. Habermas deseja revelar aspectos dos processos históricos que foram ignorados e reformular os diagnósticos fornecidos. A teoria do agir comunicativo pretende relevar o potencial da racionalidade comunicativa. De acordo com Habermas, a passagem das sociedades primitivas para a modernidade é marcada pela disjunção entre mundo da vida e sistema e pela colonização do mundo vivido por mecanismos de integração sistêmicos, de modo que a ação comunicativa vai sendo substituída pela estratégica. Na sua proposta crítica, a teoria do agir comunicativo denuncia elementos bloqueadores da razão prática e (não por acaso de modo coincidente) patologias advindas da colonização do mundo da vida (HABERMAS, 2012b). 


\section{Noções Habermasianas mais referenciadas}

Conforme apresentado na seção anterior, as obras "Teoria do agir comunicativo: racionalidade da ação e racionalização social" e "Teoria do agir comunicativo: sobre a crítica da razão funcionalista" estiveram presentes, em conjunto, no tratamento de todos os temas, exceto no de "Economia Solidária", quando foi referenciada apenas a segunda. Desse modo, caso se considere a obra "Teoria do agir comunicativo" como um todo, tem-se que ela está presente em todos os temas. Pela análise qualitativa, encontraram-se em todos os temas noções abordadas na obra magna do autor, "ação estratégica/comunicativa", "racionalidade instrumental/comunicativa" e "mundo da vida/sistema". Ao fundamentarem seus trabalhos na teoria do agir comunicativo, os autores muitas vezes utilizam-se desses conceitos sincronicamente, de forma complementar, a fim de oferecerem uma visão ampla da teoria em que se baseiam. O enfoque dado a essas noções varia, todavia, entre as pesquisas. Na sequência, considera-se a forma como os temas se relacionam com o pensamento habermasiano, tomando-se por base as noções habermasianas constatadas nas publicações.

As principais teorias sociológicas da ação assemelham-se em suas compreensões sobre a noção de ação: "a realização de um plano de ação que se apoia numa interpretação da situação. Ao executar um plano de ação, o ator resolve uma situação" (HABERMAS, 2010, p. 139). Contudo, essas teorias diferenciamse no entendimento dos mecanismos que coordenação a ação, quais sejam: o mútuo acordo, quando os atores aceitam um saber como válido, intersubjetivamente vinculativo, e os motivos associados às convicções podem ser tomados como recursos para a compreensão do outro; ou a influência externa, que não produz o efeito vinculativo nem permite que os motivos associados possam ser utilizados como recursos para a compreensão, pois o importante é a influência sobre as decisões do adversário, independentemente do meio a que se recorra (HABERMAS, 2010).

Com essa compreensão dual de ações relacionam-se os conceitos de ação comunicativa e ação estratégica - a primeira, compreendida como uma interação interpessoal entre pelo menos dois sujeitos na qual "os atores buscam um entendimento sobre a situação da ação para, de maneira concordante, coordenar seus planos de ação e, e com isso, suas ações" (HABERMAS, 2012, p. 166); a segunda, como ampliação da ação teleológica, na qual o indivíduo age orientado por fins e "se supõe que o ator escolhe e calcula os meios e fins segundo aspectos da maximização do proveito ou das expectativas de proveito" (HABERMAS, 2012, p. 164). Na ação comunicativa, a linguagem assume o papel de mecanismo de coordenação da ação. Já na ação estratégica, a linguagem é apenas mais um dos meios para que os atores orientados pelos próprios êxitos atuem uns sobre os outros de acordo com interesses egocêntricos (HABERMAS, 2012a).

As noções de ação comunicativa e ação estratégica estiveram presentes em todos os temas como suporte à teoria do agir comunicativo. Receberam maior enfoque, contudo, nos temas "Comunicação", "Educação" e "Teoria das Organizações" (Estratégia, Conceito de ação, Conceito de Racionalidade, Gestão Social, Razão Substantiva).

Com relação ao tema "Comunicação", as noções de ação estratégica e ação comunicativa são utilizadas para problematizar a comunicação organizacional, que, correntemente, constitui uma prática utilitária, limitada e hierárquica, que visa influenciar decisões e modificar os subordinados, a fim de se alcançarem os objetivos organizacionais. Propõe-se, com apoio no pensamento habermasiano, outro modelo de prática comunicacional, no qual qualquer participante da interação ou da negociação possa questionar outro sem coerção ou qualquer outra influência, um processo no qual as argumentações sejam embasadas em uma racionalidade adequada ao contexto, para a resolução das situações.

Por exemplo, Matitz e Vizeu (2013) procuram investigar, sob a ótica da ação comunicativa, como as declarações de missões empresárias, ferramenta importante da gestão estratégica, pode funcionar como uma distorção na comunicação, servindo para manipular a sociedade e desviar a atenção das atividades potencialmente negativas da empresa. Essa tese é conduzida em nível amplo. Embora não se 
operacionalizem diretamente as pretensões de validade da fala segundo o ideal habermasiano de ação comunicativa (HABERMAS, 2012a), percebe-se, seguindo-se a perspectiva do estudo, que as organizações atentam contra a pretensão de veracidade, pois não visam realmente aquilo que declaram em suas missões.

Já no estudo realizado por Cardoso (2006), o referencial habermasiano é utilizado para problematizar enfoques reducionistas sobre a comunicação organizacional, tradicionalmente abordada com vistas à produção da melhor mensagem e do melhor meio para que a organização possa manipular stakeholders e atingir seus objetivos. A contribuição fundamental de Habermas para se pensar a comunicação organizacional e superar as visões reducionistas é no sentido de que o processo dialógico contemple os pressupostos da ação comunicativa, os quais garantem a qualquer participante do diálogo o direito de questionar os enunciados dos demais sem recorrer à coerção, visando-se um consenso racionalmente motivado pelo melhor argumento.

No que diz respeito ao tema "Educação", as noções de ação estratégica e ação comunicativa são abordadas apontando-se para a necessidade de novas formas de ensino e pesquisa, não mais pautadas na ação instrumental (estratégica), e sim na ação comunicativa, não prescritiva. Sugere-se ainda o rompimento com o paradigma dominante, de modo que ensino e pesquisa superem a ênfase em organizações burocráticas onde predominam ações orientadas ao êxito e passem a estudar novas alternativas de processos de gestão e organização, movimentos sociais, culturas, processos de organizar, comunicação, constituição dos sujeitos e as inter-relações e tensões entre os tópicos mencionados.

Garcia et al. (2018) procuram estabelecer relações ontológicas, epistemológicas e metodológicas entre Paulo Freire e Jürgen Habermas, a fim de discutir a constituição de sujeitos crítico-reflexivos. É manifesta neste trabalho a importância conferida ao diálogo, pelo qual diferentes atores devem engajar-se simetricamente na construção de novas formas de ensino e prática, construídas a partir dos sujeitos e seus mundos da vida, visando à formação de sujeitos reflexivos, capazes de superar discriminações, desigualdades e ideologias naturalizadas. Alinhadamente com o pensamento habermasiano (HABERMAS, 2012a), pode-se afirmar que a argumentação própria ao agir comunicativo está intimamente ligada à noção de aprendizagem. Trata-se de um processo em que as exteriorizações de um ator são fundamentadas e passíveis de refutação, permitindo-se um conhecimento que vai além de meras relações causais. Pelo processo argumentativo do agir comunicativo os atores são capazes de aprender de forma crítica.

No tratamento do tema "Teoria das Organizações", as noções de ação estratégica e ação comunicativa são utilizadas para ressaltar as contribuições habermasianas para os estudos organizacionais bem como as potencialidades que possuem para aplicação nessa área de estudo. As noções são também consideradas como possíveis bases para aproximação, crítica ou complementariedade dirigidas a outras teorias organizacionais, tais como "Estratégia como Prática" e "Gestão Social”. Para Zwick, Silva e Brito (2014), a abordagem emergente da "Estratégia como Prática" pode beneficiar-se do referencial habermasiano, compreendendo-se que a ação comunicativa fornece um novo modelo, segundo o qual uma estratégia considerada como prática deve ser construída a partir de critérios democráticos, visando-se o entendimento consensual dos sujeitos. A estratégia a ser implantada deve ser aquela que for considerada mais adequada ao contexto histórico e social em que os atores estão envoltos. Nisso nota-se a importância da linguagem como meio coordenador da ação, mesmo em ambientes sistêmicos, nos quais os mecanismos próprios de coordenação são o dinheiro e o poder. Trata-se, portanto, de espécie de extensão do agir próprio do mundo da vida para dentro do sistema, contraposição ao movimento de colonização do mundo da vida que gera patologias sociais (HABERMAS, 2012b).

Já na perspectiva da Gestão Social, utilizam-se noções habermasianas para analisar a implementação de ações afirmativas por meio de participações intersetoriais. Lorenzo (2012) busca compreender a validade dos discursos dos diferentes parceiros envolvidos em uma ação afirmativa para jovens negros no Brasil. Verificam-se inconsistências no projeto, concebido para atender ao modelo dialógico e participativo da 
gestão social. Entre os achados, a pesquisa evidenciou que os envolvidos discordavam a respeito dos assuntos a serem tematizados e consensualmente acordados e também que situações dialógicas não coercitivas nem sempre foram conduzidas, excluindo-se das reuniões dos parceiros atores importantes para a gestão social do projeto. Pesquisas como essa demonstram a potencialidade do referencial habermasiano para "desmascarar" práticas de gestão social. Ao basear-se na ideia de ação comunicativa, um processo de gestão participativa, além de visar o consenso entre as partes, não poderia excluir da deliberação atores legítimos, pois isso infringiria os pressupostos do modelo comunicativo habermasiano (HABERMAS, 2012a). As noções de ação estratégica e ação comunicativa são utilizadas, ademais, para discutir o conceito de ação e suas transformações ao longo tempo, conceito importante para os estudos organizacionais.

Outras noções com grande presença nas publicações são as de racionalidade instrumental e racionalidade comunicativa. A racionalidade instrumental é própria da ação orientada ao êxito. É uma racionalidade baseada em cálculos utilitários relacionados a consequências, que não centraliza questões atinentes a normas e valores. Esse foi o tipo de racionalidade que se difundiu por meio do empirismo, influenciando o modo como a modernidade reflete sobre si mesma, e que, sobressaído, inibiu a concretização dos ideais emancipatórios do iluminismo (HABERMAS, 2010).

Habermas considera, todavia, parcial esse conceito de racionalidade. Há, para ele, uma racionalidade outra embutida na prática comunicativa, que não se baseia apenas no mundo objetivo, mas deve fazer valer pretensões de validade referentes aos mundos objetivo, social e subjetivo. Isso implica que qualquer ato de fala orientado para o entendimento pode ser rejeitado sob três aspectos: correção, verdade e sinceridade (HABERMAS, 2010). A racionalidade comunicativa visa o consenso próprio à fala argumentativa, na qual os participantes "superam suas concepções inicialmente subjetivas para então, graças à concordância de convicções racionalmente motivadas, assegurar-se ao mesmo tempo da unidade do mundo objetivo e da intersubjetividade de seu contexto vital” (HABERMAS, 2012a, p. 35 e 36 ).

As noções de racionalidade instrumental e comunicativa também estão presentes em todos os temas, muitas vezes atreladas aos tipos de ação, como a racionalidade subjacente a cada qual. Os temas nos quais as noções de racionalidade instrumental e comunicativa sobrelevam-se são "Comunicação", "Economia Solidária", "Educação" e "Teoria das Organizações".

$\mathrm{Na}$ abordagem do tema "Comunicação", as noções de racionalidade instrumental e comunicativa são utilizadas para compreender a racionalidade ético-comunicativa como antagônica à racionalidade instrumental, sob o argumento de que valores ético-morais são construídos nas interações entre indivíduos, frutos de uma racionalidade dialógica, portanto. Essas noções são também utilizadas para debater a lógica do discurso gerencial, predominantemente orientado por uma razão instrumental que imprime nos indivíduos valores não referentes a eles próprios e pela qual se objetiva dominação. Freddo (1991) entende as organizações como estruturas de interação comunicativa, em que os indivíduos podem a vir a agir orientados por uma racionalidade comunicativa. Contudo, considera que a razão instrumental do discurso gerencial predomina no ambiente interno das organizações, tornando-as local de dominação, frustração, desinformação, manipulação e conformismo. Defende-se então a viabilidade da razão comunicativa para indicar vias de emancipação. Tais reflexões sobre as razões que orientam o ambiente interno das organizações são pertinentes e poderiam ser complementadas com as noções habermasianas de trabalho e interação, presentes em sua obra "Técnica e Ciência como 'Ideologia" (HABERMAS, 2014), servindo para delimitação dos domínios organizacionais internos onde predominam um ou outro tipo de racionalidade.

No tema "Economia Solidária", o recurso à noção de racionalidade comunicativa guarda relação de interesse com a pragmática universal, a qual almeja identificar e reconstruir as condições universais de compreensão mútua. O compreender está na essência da economia solidária, um modelo econômico baseado na união, que prioriza necessidades econômicas comuns. Nesse sentido, Gomes (2014) vê na economia solidária a possibilidade de afirmação da proposta habermasiana de interação comunicacional 
fundamentada nos princípios da pragmática universal. A economia solidária, considerada como um processo autogestionário, tem como premissa básica o empenho dos agentes em atingir uma compreensão mútua dos mecanismos de gestão. O ponto central de convergência é a coletividade, que, na teoria habermasiana, vê possibilitada a emancipação por meio da interação em favor de ideias socialmente aceitas e coletivamente construídas. $\mathrm{Na}$ economia solidária, a união dos indivíduos visa sanar as necessidades econômicas comuns. Evidencia-se aí o potencial crítico do referencial habermasiano, nos moldes engendrados na tradição crítica alemã, no sentido de se encontrarem na realidade posta potenciais de emancipação (NOBRE, 2008). Sua aplicação ao modelo da economia solidária indica a possiblidade efetiva de sustentar teórica e empiricamente, dentro do próprio capitalismo, modelos de gestão não redutíveis à racionalidade instrumental predominante no sistema.

As noções de racionalidade instrumental e comunicativa, na abordagem do tema "Educação" são utilizadas para discutir a epistemologia frequentemente empregada nos estudos e pesquisas em Administração, em especial em Administração Pública. Tematiza-se a predominância de trabalhos segundo a razão instrumental, própria da corrente positivista. A racionalidade comunicativa é vista como uma alternativa, por envolver processos dialógicos entre os atores da cena social e aqueles que estão incumbidos de sua gestão, o que é deveras pertinente em se tratando de administração pública.

Abreu (2010) aponta que há uma contradição entre a natureza do conhecimento em administração (interdisciplinar e multidimensional) e a realidade da administração, que, imersa em razão instrumental, limita a atuação do administrador à dimensão do mercado. Com isso, as instituições de formação de administradores empregam um programa pedagógico utilitarista, fragmentado e sem integração interdisciplinar. $\mathrm{O}$ administrador público torna-se então capaz de entender a realidade, mas não de transformá-la e colaborar para a emancipação social dos indivíduos e da própria administração. Eles são peritos, mas não políticos que dialogam. Para o autor, a administração pública é um conjunto de processos e funções que devem focar a gestão do Estado, de onde o exercício do poder emana e onde é exercido pelo povo. Assim, ela deve ser direcionada pela razão comunicativa que implica atividades dialógicas entre os envolvidos na gestão.

Tais críticas vão ao encontro do diagnóstico apresentado por Habermas no que tange - poderíamos dizer - à tendência à cientificização da política. Para ele o Estado ou o político (agente da administração pública) tonaram-se executores de uma inteligência científica, pautada no saber técnico de uma racionalidade instrumental que otimiza os imperativos de controle. Com isso, os agentes da administração pública excluem do debate questões práticas relacionadas a valores e que deveriam orientar o próprio desenvolvimento da técnica para a satisfação das necessidades sociais (HABERMAS, 2014). A formação de administradores públicos, conforme Abreu (2010), contribui ainda mais para essa cientificização, construída a partir de pressupostos utilitaristas, técnicos, não necessariamente voltados para a realização de gestão participativa.

Por fim, na abordagem do tema "Teoria das Organizações", as noções de racionalidade instrumental e comunicativa são empregadas com o fim de: ampliar o debate sobre o conceito de racionalidade no campo da teoria organizacional; possibilitar uma análise crítica do processo de dominação que subjaz aos modelos de organizações flexíveis, devido à racionalização das relações cotidianas, bem ainda do fenômeno da liderança transformacional, evitando-se concepções ingênuas. Vale destacar, além disso, o emprego dessas mesmas noções para estabelecer uma aproximação teórica com a teoria da razão substantiva de Guerreiro Ramos, apontando-se para complementariedades entre as teorias e potencialidades de estudos organizacionais com viés crítico.

Para Silveira (2008), a ideia de racionalidade foi aplicada aos estudos organizacionais inicialmente sob uma perspectiva na qual ela seria a responsável por garantir a prosperidade e a ordem. Isso se alinhava ao modelo capitalista em expansão, que impunha às organizações a função de tornar o comportamento humano intencionalmente racional, regular e modelar os comportamentos individuais e coletivos, a fim de se obter eficiência e lucro. Habermas é apresentado como exemplo de autores que introduziram um 
pensamento mais ampliado sobre as ideias de razão e racionalidade. Contribui-se para os estudos organizacionais ao subsidiar o entendimento de que o sentido do trabalho no sistema capitalista não pode ser estruturado apenas por uma razão instrumental que coloca obstáculos à emancipação, mas a partir de uma racionalidade comunicativa que, pela a ação compartilhada entre os indivíduos, proporcione o alcance de um bem social maior. Segundo o autor, buscar uma ideia mais ampla de racionalidade no âmbito das abordagens organizacionais permite uma aproximação do entendimento do complexo emaranhado de variáveis que configuram a ação e o sentido que os sujeitos constroem nas organizações. Todavia, embora se defenda que a noção de racionalidade habermasiana seja mais ampla do que a oferecida pelo racionalismo, não se esmiúça o modo como o filósofo a amplia. Entre outros aspectos, poder-se-ia mencionar a tríplice referência ontológica aos mundos objetivo, social e subjetivo, necessários para validar uma exteriorização conforme a razão comunicativa, em oposição à referência unidimensional ao mundo objetivo conforme a razão instrumental (HABERMAS, 2012a).

Souza e Ornelas (2015) utilizam o conceito habermasiano de racionalidade comunicativa para apontar suas complementaridades e delimitações em relação à ideia de racionalidade substantiva tal qual desenvolvida por Guerreiro Ramos, ambas opostas à racionalidade instrumental, hegemônica na sociedade moderna industrial. Os autores compreendem que Habermas se aproxima de Guerreiro Ramos ao introduzir na estrutura conceitual do agir comunicativo características intrínsecas da psique humana, como personalidade, integridade pessoal, juízo e consciência autônoma, podendo-se falar em substantividade da racionalidade comunicativa. E Guerreiro Ramos aproxima-se de Habermas, especialmente no que tange à ideia de democracia deliberativa, ao propor a deliberação como via para a promoção de uma boa sociedade, podendo-se falar em uma espécie de comunicatividade da racionalidade substantiva.

Outra díade recorrente nas publicações é aquela constituída de mundo da vida e sistema. A teoria do agir comunicativo procura superar a unidimensionalidade então característica de algumas abordagens sociais, incorporando à explicação das sociedades as noções de mundo da vida e sistema, âmbitos marcados por modos distintos de integração (HABERMAS, 2010). Por essa perspectiva dual de sociedade, o mundo da vida é definido como "um reservatório de autoevidências e convicções inabaláveis, do qual os participantes da comunicação lançam mão quando se encontram em processos cooperativos de interpretação" (HABERMAS, 2012b, p. 228). Sua reprodução simbólica ocorre pela ação comunicativa. Nele, as ações são integradas por um consenso garantido por normas ou obtido pelas vias da comunicação.

O sistema, por outro lado, constitui uma dimensão que se reporta à natureza estratégica das relações sociais. Baseado em autores como Niklas Luhmann e Talcott Parsons, Habermas releva a abordagem sistêmica da sociedade:

[...] sociedades modernas são integradas não somente através de valores, normas e processos de entendimento, mas também sistemicamente, através de mercados e do poder administrativo. Dinheiro e poder administrativo constituem mecanismos da integração social (HABERMAS, 1997, p. 61).

Habermas salienta a instauração, na modernidade, de um desequilíbrio entre mundo da vida e sistema, a colonização do mundo da vida pelo sistema; as formas de racionalidade econômica e administrativa promovem um processo de racionalização unilateral da prática comunicativa cotidiana. Idealmente, as racionalidades não deveriam extrapolar os âmbitos às quais são inerentes. As noções de mundo da vida e sistema destacam-se na abordagem dos temas "Administração Pública", "Educação" e "Teoria das Organizações". Tal como noções anteriormente expostas, também estas estão presentes em todos os temas.

No tema "Administração Pública", as noções de mundo da vida e sistema são utilizadas com o fim de analisar o processo de racionalização de um evento nascido da cultura popular pelas lógicas de mercado e pela administração pública. Leão et al. (2017) estudaram a coexistência de mundo da vida e sistema no 
evento São João de Campina Grande, um festejo que, em sua origem, era familiar, organizado em fazendas das proximidades ou espaços públicos, e que, posteriormente, foi assumido pela administração pública. Para os autores, o Estado, ao assumir a organização do festejo, atuou de forma estratégica e finalística a fim de atingir os objetivos da Administração Pública e de agentes privados, realizando a colonização sistêmica da festa junina, antes movida pelo entendimento mútuo. Os efeitos dessa colonização são percebidos nos discursos dos entrevistados, que ressaltam aspectos como vantagens, lucratividade, especialização, segmentação e exploração no atual formato do evento. Trabalhos como esse são importantes por permitirem elucidar aquilo que foi pensado por Habermas em âmbito teórico. A pesquisa estimula uma análise crítica da atuação de governo e do mercado, agentes que notadamente caracterizados pela atuação sistêmica. O projeto habermasiano propulsiona a racionalidade comunicativa, integradora do mundo da vida. Ao direito é reservado um importante papel, o de transformar o poder comunicativo gerado da deliberação em poder administrativo legítimo para integração sistêmica (HABERMAS, 1997)

$\mathrm{Na}$ abordagem do tema "Educação", as noções são utilizadas para defender o paradigma comunicativo de Habermas na realização de pesquisas em estudos organizacionais, como forma de superar, por meio de uma compreensão dual da sociedade, visões unilaterais. Rivera (1995) defende uma perspectiva integradora sobre as visões de organização. Entende ser necessária uma reconciliação dialética entre visões macro e determinísticas, como a sistêmica, e visões micro e voluntaristas, como a da integração social. Para o autor, o referencial habermasiano é capaz de operacionalizar tal reconciliação via alargamento da comunicação, de modo que valores, ideias, ordenamentos e capacidades provenientes do mundo da vida dos sujeitos impregnem e conduzam a organização enquanto totalidade sistêmica. Para tanto, é necessária uma mudança epistemológica que substitua nas teorias organizacionais a categoria sujeito (paradigma da consciência) pela categoria intersubjetividade linguisticamente mediada (paradigma comunicativo).

Por fim, sob a perspectiva da "Gestão social", no tema “Teoria das Organizações", as noções de mundo da vida e sistema são utilizadas para discutir o locus da gestão social. Trata-se de uma tentativa de superar a compreensão que situa a gestão epistemologicamente e socialmente em polos excludentes. Os autores defendem o lócus da gestão social no contexto das inter-relações e tensões entre mundo da vida e sistema, o que para eles, é propiciado pela própria mudança de postura de Habermas quanto às categorias sistema e mundo da vida. Segundo os autores, na obra Direito e Democracia, as fronteiras entre esses conceitos tornam-se mais fluidas e suas diferenças, menos rígidas do que quando apresentadas na Teoria do Agir Comunicativo. Uma concepção relacional e não dicotômica das relações entre mudo da vida e sistema permite diagnósticos mais coerentes e críticos das patologias sociais e relações de dominação, bem como dos potenciais de emancipação. As noções são também utilizadas para gerar aproximação teórica com outros autores, com a finalidade de esclarecer epistemologicamente o processo de gestão de avaliação em gestão social, que objetiva analisar fatos, valores e seus significados intersubjetivamente compartilhados (ALCÂNTARA et al., 2017).

O objetivo desta seção foi apresentar as noções habermasianas mais utilizadas nas publicações analisadas. Em menor número, outras noções habermasianas também foram utilizadas, como democracia deliberativa, esfera pública e ética discursiva. Entre elas, destaque-se a utilização da noção de esfera pública no tema "Teoria das Organizações", em discussões sobre teoria da gestão social, especialmente utilizada pelos autores mais produtivos (DE OLIVEIRA; CANÇADO; PEREIRA, 2010; GARCIA et al., 2018; GARCIA et al., 2019).

\section{Abordagens de Pesquisa Utilizadas}

Conforme enunciado, o levantamento bibliométrico também se destinou a identificar os métodos de pesquisa empregados pelos autores. Verificou-se que a maior parte das publicações, 35 textos, compreende ensaios teóricos. As 11 publicações restantes compreendem pesquisas empíricas, que se utilizam da metodologia de estudo de caso. 
Os ensaios versam sobre os temas "Administração Pública", "Educação", "Comunicação" e "Teoria das Organizações". Segundo Meneghetti (2011, p. 321), o ensaio teórico "requer sujeitos, ensaísta e leitor, capazes de avaliarem que a compreensão da realidade também ocorre de outras formas", ou seja, constitui um modo de se fazer pesquisa diferente daquele priorizado pelo método tradicional. A opção pelo ensaio teórico pode, em alguma medida, guardar relação com o referencial trabalhado. Relembre-se que a epistemologia crítica impugna o positivismo. O ensaio teórico permite ao ensaísta gozar de liberdade retórica e de pensamento, o que promove originalidade argumentativa derivada da constante interação entre sujeito e objeto (MENEGHETTI, 2011).

No ensaio teórico, não se aprisiona a determinado dogmatismo epistemológico. O ensaísta pode aproveitar-se do caráter experimental do ensaio para combinar epistemologias de forma interdisciplinar, sendo até mesmo aceitáveis possíveis contradições surgidas dessas construções. Todavia, alguns pressupostos e fundamentos básicos devem ser respeitados a fim de não tornar a argumentação incompreensível. O ensaio busca a construção da argumentação de maneira adequada, mesmo que esta não exista a princípio (MENEGHETTI, 2011). Seu objeto de análise pode ser "material ou imaterial, concreto ou abstrato, mas sempre é real, pois existe enquanto algo que aparece, possui essência e é cognoscível na totalidade" (MENEGHETTI, 2011, p. 324). Destaca-se ainda que a subjetividade do ensaísta está em constante interação com o objeto e tem papel fundamental em como o ensaio avança como processo de conhecimento. Esse tipo de trabalho é um importante recurso para ampliar a interdisciplinaridade e fomentar a construção de conhecimento intersubjetivo, com grande potencialidade para os estudos em Administração (MENEGHETTI, 2011).

As pesquisas empíricas versam sobre os temas "Administração Pública", "Educação", "Economia Solidária", "Comunicação" e "Teoria das Organizações", ou seja, sobre todos os temas identificados. A abordagem qualitativa utilizada nesses estudos procura superar o tratamento estatístico dos métodos quantitativos, pois o pesquisador emprega métodos e técnicas que reúnem informações com a interação dos pesquisados, permitindo a pesquisa qualitativa ser capaz de descrever, interpretar e explicar. Os procedimentos que permitem a obtenção das informações pertinentes ao problema de pesquisa na abordagem qualitativa são entrevistas, observações, análise de documentos e artefatos (MERRIAN, 2009; RICHARDSON, 2017). Um dos tipos de pesquisa que acolhe a abordagem qualitativa é o estudo de caso, no qual um fenômeno social constitui um objeto a ser profundamente analisado (MERRIAN, 2009; TRIVIÑOS, 1987).

\section{Considerações finais}

Objetivou-se neste artigo realizar uma exploração bibliográfica, por uma abordagem de viés quantitativo e qualitativo, da produção acadêmica em estudos organizacionais, na área de Administração, que utiliza Habermas como referencial nas suas discussões. Frise-se que estudos como o conduzido não deixam de portar o fito de legitimar a relação entre pensamento reflexivo e teorização organizacional.

Pela análise quantitativa e descritiva, constatou-se que as publicações em estudos organizacionais na área de Administração fundamentadas em teorias habermasianas, embora se tenham iniciado na década de noventa, somente em anos mais recentes experimentaram um crescimento mais expressivo em volume. Fato que chama atenção é a concentração das publicações em periódicos da Fundação Getúlio Vargas, receptivos ao recorte teórico visado. O periódico que contém mais publicações desse tipo é o Cadernos EBAPE.BR, responsável pelo ano mais profícuo (2014) e também aparecendo em outros três anos com o maior volume de publicações (2011, 2015 e 2018). Tal fato parece relacionar-se não apenas com o incentivo extraordinário representado pela chamada especial, mas igualmente pela abertura permanente do periódico a estudos com abordagens críticas, entre as quais as embasadas em teóricos frankfurtianos.

Também foi observado que os autores mais profícuos são José Roberto Pereira e Valderí de Castro Alcântara, que, na maior parte das vezes, trabalham conjuntamente. A alta produtividade desses autores dentro do recorte visado possivelmente guarde relação com as atividades que desenvolvem, 
fundamentadas no referencial habermasiano, como projetos de pesquisa, participação em eventos científicos e orientações de pós-graduação. Além disso, a relação entre orientador e orientando é duradoura. Outras constatações foram: a instituição com o maior número de autores vinculados é a Universidade Federal de Lavras, à qual se filiam os dois autores mais produtivos; a maior parte dos autores tem como área de atuação a Administração (como de se esperar em função do recorte procedido); e a obra de Habermas mais referenciada é Teoria do Agir Comunicativo.

Complementarmente, pela análise qualitativa, verificaram-se os temas presentes nas publicações e captouse como as noções habermasianas foram utilizadas na construção dos trabalhos. Os temas mais recorrentes são "Administração Pública", "Economia Solidária", "Educação", "Comunicação" e "Teoria das Organizações". As obras habermasianas mais referenciadas são "Teoria do agir comunicativo: racionalidade da ação e racionalização social" e "Teoria do agir comunicativo: sobre a crítica da razão funcionalista", os dois volumes constituintes da obra magna do autor. Os conceitos habermasianos mais presentes são os integrantes das díades "ação estratégica/comunicativa", "racionalidade instrumental/comunicativa" e "mundo da vida/sistema". E o tipo de trabalho mais frequente é o ensaio teórico, conquanto não seja insignificante o volume de estudos de caso.

Os temas das publicações não são muitos. Pode-se até considerar relativamente diminuta a variedade. As discussões estão principalmente relacionadas à "Educação" (pesquisa, docência e ensino em estudos organizacionais), apontando para a necessidade e para as potencialidades de abordagens de cunho crítico na área, e à "Teoria das Organizações" em geral, debatendo conceitos centrais, como ação e racionalidade, e estimulando aproximações teóricas a abordagens da "Gestão Social" e da "Razão Substantiva". Esses temas são tratados especialmente a partir de reflexões teóricas e, quando atrelados à pesquisa empírica, por abordagem qualitativa.

Embora os temas não sejam muitos, percebe-se que o referencial habermasiano permite aplicações sob diferentes perspectivas e a diferentes níveis do fenômeno organizacional. É empregado para analisar: discursos; práticas de gestão, ensino e comunicação em organizações privadas e públicas; atuações racionalizadoras e instrumentais da administração pública e do mercado sobre eventos originários do mundo da vida; epistemologias dos conhecimentos gerados em estudos organizacionais; e a própria concepção de organização.

Diante do apresentado, as contribuições desta pesquisa residem, primeiramente, no reforço do argumento de que as teorias de Habermas possuem potencial para a realização de estudos críticos, teóricos e empíricos, na área dos estudos organizacionais. Mesmo muitas de suas obras não sendo recentes, oferecem subsídios altamente proveitosos para a compreensão dos fenômenos organizacionais contemporâneos, como demonstram os trabalhos compilados. A identificação dos temas trabalhados e das noções habermasianas mais utilizadas contribui para que pesquisadores interessados aprofundem temas e noções já estudados ou se lancem ao estudo de novos temas, empregando noções habermasianas ainda pouco exploradas - gerando-se, por conseguinte, respectivamente, consolidação ou inovação.

Apresenta-se como limitação desta pesquisa a restrição ao cenário nacional. Seria de alta valia entender como se têm processado publicações em contextos estrangeiros, especialmente aqueles mais influentes dos estudos brasileiros. Da mesma forma, a opção por revistas classificadas entre A1 e B1 deixa de fora muitos dos periódicos nacionais. Um novo estudo que abrangesse um intervalo classificatório mais amplo poderia verificar a existência de outros temas e noções habermasianas não privilegiados nos periódicos analisados. Por fim, registre-se que o número relativamente alto de publicações da amostra analisada dificulta um tratamento mais aprofundado dos dados.

Sugere-se que novas pesquisas em estudos organizacionais apoiadas no referencial habermasiano explorem outras teorias do autor. A despeito de proveitosos os conceitos utilizados, há muito mais no pensamento habermasiano. Particularmente, as noções de esfera pública e de direito em Habermas podem ser altamente profícuas para estender o alcance explicativo de fenômenos quais a forma como 
atualmente se dá a relação entre empresa e setor público e a forma como a empresa recebe postulações relativas à governança corporativa. Ademais, no bojo do projeto habermasiano, relembre-se que, juntamente com o potencial explicativo fornecido por sua teoria, vem um potencial transformador típico da postura crítica propositiva. Comparações posteriores, entre os contextos nacional e estrangeiro, possivelmente suportariam compreensões mais consequentes acerca da maneira como se tem desenvolvido o recorte visado. Para mais, sugere-se arriscar o uso de outros procedimentos metodológicos. Dentro da própria abordagem qualitativa, pode fazer sentido explorar outras maneiras, além daqueles presentes nas publicações, para analisar a empiria com fundamento na teoria habermasiana.

\section{Referências}

ABREU, J. C. A.; Modelos Epistemológicos na Administração Pública: O Discurso Substantivo em Habermas acerca da Democracia na Sociedade da Informação. Administração Pública e Gestão Social, v.2, n.1, p.1-20, 2010.

ALCÂNTARA, V. C.; CABRAL, E. H. S.; MUZY, P. T.; PEREIRA, J. R.. Fatos, valores e o mundo-davida: argumentos epistemológicos para avaliação no âmbito da gestão social. Cadernos EBAPE. BR, v. 15, n. 4: p. 808-830, 2017.

ALCÂNTARA, V. C.; PEREIRA, J., R. O locus da gestão social no contexto das inter-relações e tensões entre mundo-da-vida (lebenswelt) e sistema (system). Organizações \& Sociedade, v. 24, n. 82, p. 412431, 2017.

BANNWART JUNIOR, C. J.; FAVORETO, R. L.; NOGUEIRA, A. J. F. M. Trabalho e interação: reminiscências da dialética habermasiana. In: V Congresso Brasileiro de Estudos Organizacionais (VCBEO), 2018, Curitiba. Anais do V Congresso Brasileiro de Estudos Organizacionais (VCBEO), 2018.

BURRELL, G.; MORGAN, G. Sociological paradigms and organizational analysis: elements of the sociology of corporate life. Hants: Ashgate, 1979.

BURRELL, G. Modernism, Postmodernism and Organizational Analysis 4: The Contribution of Jürgen Habermas. Organization Studies, v. 15, n.1, p. 1-45, 1994

CARDOSO, O. O. Comunicação empresarial versus comunicação organizacional: novos desafios teóricos. Revista de Administração Pública, v.40, n.6, 1123-1124, 2006.

COOPER, R.; BURREL, G. Modernism, Postmodernism and Organizational Analysis: An Introduction. Organization Studies, v. 9, n.1, p. 91-112, 1988.

DE OLIVEIRA, V., A., R.; CANÇADO, A., C.; PEREIRA, J., R. Gestão social e esfera pública: aproximações teórico-conceituais. Cadernos EBAPE.BR, v. 8, n. 4, p. 613-626, 2010.

DUPEYRIX, Alexandre. Compreender Habermas. Tradução de Edson Bini. São Paulo: Edições Loyola, 2012.

FAVORETO, R. L.; NOGUEIRA, A. J. F. M.; BANNWART JUNIOR, C. J. Pensamento habermasiano e Administração. Organizações e Sustentabilidade, v. 7, p. 7-10, 2019.

FOURNIER, V.; GREY, C. At the critical moment: Conditions and prospects for critical management. Human Relations, v. 53, n. 1, p. 7-32, 2000.

FREDDO, A., C. Poder e violência como ação estratégica. Revista de Administração Pública, v. 29, n.3, 111-121, 1995.

GARCIA, A. S.; PEREIRA, J. R.; ALCÂNTARA, V. C.; CRUZ, E. S. T. Aprofundamento das esferas públicas para a gestão social: caminhos para uma reconstrução empírico-descritiva e normativa. Cadernos EBAPE. BR, v. 16 n .2: p. 163-185, 2018. 
GARCIA, A. S.; PEREIRA, J. R.; ALCÂNTARA, V. C.; PRADO, J. W. Produção científica sobre esfera pública: um Estudo Bibliométrico em Múltiplas Áreas do Conhecimento (1970-2015). Administração Pública e Gestão Social, v. 11, n. 1, p. 2-15, 2019.

GIL, A. C. Como elaborar projetos de pesquisa. 5. ed. São Paulo: Atlas, 2010.

GOMES, F. Uma aproximação entre pragmática universal e economia solidária: o caso de Catende. Cadernos EBAPE. BR, v.12, n.3, p.416-441, 2014.

GUEDES, V. L. S.; BORSCHIVER, S. Bibliometria: uma ferramenta estatística para a gestão da informação e do conhecimento, em sistemas de informação, de comunicação e de avaliação científica e tecnológica. In: CINFORM: ENCONTRO NACIONAL DE CIÊNCIA DA INFORMAÇÃO, 5., Bahia. Anais... 2005. Disponível em: $<$ http://www.cinformanteriores.ufba.br/vi_anais/docs/VaniaLSGuedes.pdf>.Acesso em: 09 mai. 2019

HABERMAS, J. Die Einbezienhung des Anderen: Studies zur politischen Theorie. Frankfurt am Main: Suhrkamp Verlag, 1996.

Direito e democracia: entre facticidade e validade. Rio de Janeiro: Tempo Brasileiro, 1997. v.

II.

Esclarecimentos sobre o conceito de acção comunicativa. Fundamentação teóricolinguística da sociologia (Obras escolhidas de Jürgen Habermas; 1). Lisboa: Edições 70, 2010

Teoria do agir comunicativo: racionalidade da ação e racionalização social. São Paulo: Martins Fontes, 2012a. v. I

Teoria do agir comunicativo: sobre a crítica da razão funcionalista. São Paulo: Martins Fontes, 2012b. v. II

. Technik und Wissenschaft als 'Ideologie’. Frankfurt am Main: Suhrkamp Verlag, 1968

. Técnica e ciência como Ideologia. Felipe Gonçalves Silva. São Paulo: Editora Unesp, 2014. 207 p. Título original: Technick und Wissenschaft als Ideologie.

.Theorie des Kommunikativen Handelns: Handlungsrationalität und gesellschaftliche Rationalisierung. Band 1. Frankfurt am Main: Suhrkamp, 1981.

. Theorie des Kommunikativen Handelns: Zur Kritik der functionalistischen Vernuft. Band

2. Frankfurt am Main: Suhrkamp, 1981.

LAKATOS, E. M.; MARCONI, M. A. Metodologia Científica. 6. ed. São Paulo: Atlas, 2011.

LARA, L. G. A.; VIZEU, F. O potencial da frankfurtianidade de Habermas em estudos organizacionais. Cadernos EBAPE. BR, v.17, n.1, p.1-11, 2019.

LEÃO A. L. M. S.; PERDIGÃO, J. G. L.; FRANCO, S. M.; FERREIRA, B. R. T. São João de Campina Grande como megaevento: imbricamento entre sistema e mundo da vida na mercadorização da cultura. Administração Pública e Gestão Social, v.9, n.2, p.87-94, 2017.

LETRARI, H.; CHIBA, J. H. F.; DE SOUZA, R. B. Pierre Bourdieu nos estudos organizacionais: um estudo bibliométrico internacional sobre a contribuição do sociólogo nas publicações da área da administração. In: Seminário em Administração (SEMEAD), 2018, Anais XXI do Seminário em Administração (SEMEAD), 2018.

LORENZO, R. A. As Ações Afirmativas Para Afrodescendentes Articuladas a partir de Parcerias Intersetoriais: uma Análise Argumentativa do Caso Geração XXI. Organização \& Sociedade, v.19, n.63, p.697-713, 2012.

MATITZ, Q. R. S.; VIZEU, F. Organizational Sacralization and Discursive Use of Corporate Mission Statements. Brazilian Administration Review, v.10. n.2, 176-194, 2013. 
MERRIAN, S. B. Qualitative research: a guide to design and implementation. San Francisco: JosseyBass, 2009.

NOBRE, Marcos. A teoria crítica. 2a ed. Rio de Janeiro: Jorge Zahar, 2008.

PAES DE PAULA, A. P. Para além dos paradigmas nos Estudos Organizacionais: o círculo das matrizes epistêmicas. Cadernos Ebape.BR. v.14, n.1, p. 24-46, 2016.

PAO, M. L. Concepts of information retrieval. Englewood: Libraries Unlimited, 1989.

PERES JÚNIOR, M., R..; PEREIRA, J., R.; DE OLIVEIRA, L., C. Gestão social sob a lente estruturacionista. Revista de Administração Mackenzie, v. 14, n .6, p. 18-49, 2013.

PRITCHARD, Alan. Statistical Bibliography or Bibliometrics? Journal of Documentation, v.25, n.4, 348-350, 1969.

RICHARDSON, R. J. Pesquisa Social: Métodos e Técnicas. 4. ed. São Paulo: Editora Atlas, 2017.

RIVERA, F. J. U. Comunicação e gestão organizacional por compromissos. Revista de Administração Pública, v.29, n.3, 211-230, 1995.

SERVA, Maurício. A racionalidade substantiva demonstrada na prática administrativa. Revista de Administração de Empresas, v. 37, n. 2, p. 18-30, 1997a

SERVA, Maurício. Abordagem substantiva e ação comunicativa: uma complementaridade proveitosa para a teoria das organizações. Revista de Administração Pública, v. 31, n.2, p. 108-134, 1997b

SILVEIRA, V. N. S. Racionalidade e Organização: as Múltiplas Faces do Enigma. Revista de Administração Contemporânea, v.12, n.4, p.1107-1130, 2008.

SILVA, M. Racionalidade substantiva no processo decisório: um estudo em instituições que lidam com o tratamento oncológico infanto juvenil na cidade de Natal (RN). Revista de Administração Pública, v. 45, n. 5, p. 1327-1361, 2011.

SOUZA, G. C.; ORNELAS, A. L. Alberto Guerreiro Ramos e a autonomia dos estudos organizacionais críticos brasileiros: escorços de uma trajetória intelectual. Cadernos EBAPE. BR, v.13, n.3, p.438-461, 2015

SUDDABY, R.; HARDY, C.; HUY, Q. N. Introduction to special topic forum: where are the new theories of organization? Academy of Management Review, v. 36, n. 2, p. 236-246, 2011.

TRIVIÑOS, A. N. S. Introdução à Pesquisa em Ciências Sociais: a pesquisa qualitativa em educação. São Paulo: Atlas, 1987.

VANTI, N. A. P. Da bibliometria à webometria: uma exploração conceitual dos mecanismos utilizados para medir o registro da informação e a difusão do conhecimento. Ciência da Informação. Brasília, v. 31, n. 2, p. 152-162, maio/ago. 2002. Disponível em: <http://www.scielo.br/pdf/ci/v31n2/12918.pdf>. Acesso em: 09 mai. 2019

VERGARA, S.C.; CALDAS, M.P. Paradigma interpretacionista: a busca da superação do objetivismo funcionalista nos anos 1980 e 1990. Revista de Administração de Empresas, São Paulo, v.45, P.6672, 2005.

WESTWOOD, R.; CLEGG, S. The discourse of organization studies: dissensus, politics, and paradigms. In.: _ (Ed.). Debating organization: point-counterpoint in organization studies. Oxford: Blackwell Publishing, 2003.

WILLIG, C. Introducing qualitative research in psychologie: adventures in theory and method. 2. Ed. Berkshire: Open University Press, 2008.

ZWICK, E.; SILVA, I. C.; BRITO, M. J. Estratégia como prática social e teoria da ação comunicativa: possíveis aproximações teóricas. Cadernos EBAPE. BR, v.12, n.1, p.384-400, 2014. 